SAD / JSR

Sosyoloji Araştırmaları Dergisi / Journal of Sociological Research

Cilt / Volume 24 Sayı / Number 2 (Nisan / April 2021) : (320-348)
Araştırma Makelesi / Research Article

Geliş Tarihi / Submited: 29.11.2020

Kabul Tarihi / Accepted: 28.02.2021

\title{
PANDEMININ SOSYOLOJISI
}

\section{Muammer TUNA ${ }^{1}$}

\section{$\ddot{O Z Z}$}

2019 yılı Kasım ayında Çin'de ortaya çıkan COVID 19 hızla tüm dünyaya yayılmış ve 2020 yılı başında Dünya Sağlık Örgütü (WHO) tarafından Pandemi olarak tanımlanmıştır. Bununla birlikte artık dünya köklü bir şekilde değişmeye ve her şey yeniden tanımlanmaya başlanmıştır. COVID 19 Pandemisi kuşkusuz birçok farklı yönlerden irdelenebilir. Ancak bu makalede, öncelikle COVID 19 Pandemisi ile ortaya çıkan toplumsal durum analiz edilemeye çalışılmış, daha sonra da içinde bulunulan toplumsal ortamın bundan sonra hangi yöne doğru evrilebileceğine ilişkin olarak muhtemel öngörüler tartışmaya aç1lmıştır. Dolayısıyla bu makale, doğrudan bir araştırma makalesi olmamakla birlikte; COVID 19 Pandemisinin ortaya çıkışı ve yayılması sürecindeki makro sosyolojik gözlemlere ve bir ölçüde sürecin medyaya ve bilim dünyasındaki yansımaları üzerinden yapılan analizlere dayanmaktadır. Bununla birlikte, bu makalede ortaya atılan argümanlar ve varsayımlar aslen planlanmakta olan ve ön araştırması yapılmakta olan geniş kapsamlı bir sosyolojik araştırmanın temel varsayımlarının paylaşılması amacını gütmektedir. Bu bağlamda COVID 19 Pandemisi ile ortaya çıkan durumun öncelikle "kapatılmışlık”, "gözetlenmişlik” kavramlarıyla ifade edilebileceği ve bunun ötesinde yeni ortaya çıkan toplumsal durumun, internet ve sosyal medyanın etkisiyle "sanal toplum” olarak ifade edilmesinin uygun olacağı düşünülmektedir. Bu noktadan hareketle, bundan sonra toplumun hangi yöne evrilebileceğine ilişkin olarak dört varsayım öne sürülmektedir. Bunlar; dayanışma ve dayanışma ekonomilerinin yeniden gündeme gelmesi ve buna bağlı olarak sanal ağlar üzerinden bir toplumsal dayanışmanın ortaya çıkmasıdır. Bunların ötesinde, Pandemi koşullarında neoliberalizmin iflasıyla birlikte sosyal devletin yeniden gündeme gelmesi ve en son olarak doğanın yeniden keşfi ve buna bağlı olarak doğaya geri dönüş eğilimlerinin hız kazanmasıdır.

Anahtar Sözcükler: Pandemi, Kapatılmışlık, Dayanışma, Sanal Toplum, Doğaya Geri Dönüş.

${ }^{1}$ Prof. Dr., Muğla Sitk1 Koçman Üniversitesi, Edebiyat Fakültesi, Sosyoloji Bölümü

SAD / JSR

Cilt / Volume 24 Sayı / Number 2 


\section{THE SOCIOLOGY OF PANDEMIC}

\section{ABSTRACT}

COVID 19 appeared in November 2019 in China and swiftly dispersed all around the world and defined as Pandemic by World Health Organization in the early 2020. Accordingly, world has been changed deeply and everything has been redefined. COVID 19 Pandemic would be evaluated from so much different perspectives. However, the argument defended in this article is based upon that social conditions of COVID 19 Pandemic could be defined as "closedness" and "watched." Moreover, under impact of internet and social media, new social conditions defined as "virtual society." In order to fact that the four major points could be defined to understand which way the society could be evolved. Solidarity, solidarity economy and "virtual social solidarity" have been appeared as to define major factors of new society. Other factors that could be defined as major characteristics of new society are appearance of social state as a result of bankruptcy of neoliberalism and rediscovery of nature and back to nature movement. This article is not based upon a sociological field research. The argument that defended in this article is based upon a direct macro sociological observation and partly media coverage. However, the basic argumentation that is defended in this article consists of basic assumption of a planned comprehensive sociological field research.

Keywords: Pandemic, Closedness, Solidarity, Virtual Society, Back to Nature.

SAD / JSR

Cilt / Volume 24 Sayı / Number 2 


\section{GÍRİŞ}

COVID 19 Pandemisi ile ortaya çıkan toplumsal durumun incelenmesi ve araştırılması kuşkusuz sosyolojinin son bir y1lda en çok üzerinde durduğu konulardan birisi olmuştur. Bu bağlamda bu makalede öncelikle COVID 19 Pandemisi'nin dünyayı nasıl etkilediği ve nasıl bir toplumsal durumun ortaya çıtı̆̆1 ve bundan sonra toplumların ve ekonomilerin nasıl bir gelişim seyri izleyeceğine ilişkin bir değerlendirme içermektedir. Bu bağlamda öncelikle COVID 19 Pandemisi'nin nasıl bir toplumsal ve ekonomik dünyanın ortaya çıkmasına yol açtığı değerlendirilecek ve daha sonra küresel düzeyde toplumsal ve ekonomik yaşamın hangi yöne doğru evrileceğine ilişkin muhtemel olasılıklar üzerinde durulacaktır.

Bu makalede ortaya konan argümanlar, COVID 19 Pandemisi'nin ortaya çıkardığ 1 toplumsal dünyanın anlaşılmasında en uygun kavramın "risk" kavramı olduğu ve riskin yeni ortaya çıkan toplumsal durumu ortaya koyacak, kapsayıcı bir kavram olduğu düşünülmektedir. Bu bağlamda COVID 19 Pandemisi ile ortaya çıkan durumu ifade etmek/analiz etmek için kullanılacak olan "kapatılmışl1k" ve "gözetlenmişlik" kavramları da gene risk kavramı bağlamında tartışılacaktır. Ulrich Beck'in 1990'larda ortaya attığı ve 20 yy. içinde bulunduğu durumu tanımlamak için kullandığı "risk toplumu” kavramı COVID 19 Pandemisi koşullarında bir kat daha anlam kazanmıştır (1994). Riskin ötesinde öngörülemezlik, belirsizlik, güven içinde bulunamama (Lyotard, 1984; Harvey, 1990), kapatılmışlık gibi kavramlar da COVID 19 Pandemisi’nin ortaya çıkardığı ortamsal koşulları anlamak için kullanılabilecek uygun kavramlar olabilir. Bu bağlamda "risk" COVID 19 şartlarının ortaya koyduğu belirsizlik, öngörülemezlik durumlarını ifade eden bir kavramsallaştırmadır. Tüm bunların ötesinde Pandemi koşullarının gerektirdiği ve özellikle 65 yaş üstü nüfusun evlerine kapatılmasıyla oluşan karantina ve izolasyon şartlarının tam da Foucault'nun (2000) “kapatılmışlık” kavramı ile tanımladığı durumu ifade ettiği düşünülmektedir. Dolayısıyla, COVID 19 şartlarında ortaya çıkan ve risk kavramıyla ifade edilen belirsizlik ve öngörülemezlik durumu ile kapatılmışlık kavramı ile ifade edilen durum bir araya geldiğinde, depresyon gibi psikolojik duygu durumlarının ve toplumsal dayanışmanın çözülmesi gibi toplumsal duygu durumlarının ortaya çıkacağ 
ortamsal koşullar oluşmaktadır (Pfefferbaum ve Nort, 2020; Bavel vd., 2020; Fiorillo, ve Gorwood, 2020). Kapatılmışlık duygusunu somut bir ifadesi Pandemi koşullarında geniş toplum kesimlerinin sokağa çıkma kısıtlaması ile evlerinde adeta hapis olmasıdır. Kapatılmışlık duygusunun tamamlayıcı unsuru ise "gözetlenmişlik" duygusudur. Bunun somut göstergesi ise tüm dünyada 5 milyardan fazla kişinin internet ve sosyal medya araçlarını kullanması, bu kanallarla sosyalleşmeleri ve bireysel ve toplumsal yaşamlarını bu araçları kullanarak adeta tüm dünyanın gözetimine açmalarıdır. Dolayısıyla COVID 19 Pandemisinden sonucunda ortaya çıkan toplumsal durumu risk, öngörülemezlik, kapatılmış kavramlarının yanı sıra "gözetlenmişlik" kavramıyla da ifade etmenin uygun olacağı düşünülmektedir. "Gözetlenmişlik duygusu," "gözetim toplumu” kavramı ile ifade edilen durumun somut bir göstergesi olarak kabul edilebilir.

COVID 19 Pandemisi'nin yaratmış olduğu ve yukarıda değinilen ve çoğunlukla olumsuz duygu durumlarına karşı toplum bir ölçüde yeni stratejiler ve çözüm yolları geliştirmiştir denilebilir. Bunlar genel olarak, dayanışma fikrinin ve dayanışma ekonomilerinin yeniden anlam kazanması ve bu bağlamda özellikle sanal ağlar üzerinden bir toplumsal dayanışmanın ortaya çıkması, sosyal adalet, sosyal devlet gibi kavramların yeniden gündeme gelmesidir. Bunun ötesinde çevre toplum ilişkileri bağlamında, insan müdahalesi olmadığında doğanın kendisini yenileyebileceğinin farkına varılması ve bu bağlamda "doğanın yeniden keşfi”"nin ve sonuç olarak “doğaya geri dönüş” eğilimlerinin yaygınlık kazanmasıdır.

\section{COVID 19 PANDEMISI’NIN YARATTIĞI TOPLUMSAL VE EKONOMIK ORTAM}

COVID 19 Pandemisi'nin 2019 yılının sonunda ortaya çıkmış olmasına rağmen, bir yıl gibi kısa bir sürede çok hızlı bir şekilde yayılıp 2,5 milyondan fazla kişinin ölümüne ve 100 milyondan fazla kişinin enfekte olmasına yol açmış olup hastalığın nasıl bir seyir izleyeceğine ilişkin olarak bir öngörüde bulunmakta neredeyse mümkün değildir. Dolayısıyla COVID 19 Pandemisi ile ortaya çıkan süreci en iyi ifade edilecek olan en kapsayıcı kavramın risk kavramı olduğu düşünülmektedir. Bununla birlikte söz konusu toplumsal 
ortamı ifade etmek için kapatılmış, gözetlenmişlik, belirsizlik ve öngörülemezlik kavramlarının da uygun tanımlayıcı kavramlar olduğu değerlendirilmektedir.

Bu kadar hızlı yayılan ve bir aşısı bulunmuş olmasına rağmen, henüz tedavi edici bir ilacı bulunamamış olan COVID 19 ile ortaya çıkan Pandemi durumu kuşkusuz dünyayı derinden etkileme ve değiştirme potansiyeline sahip olup, bu bağlamda dünya adeta yeniden anlamlandırılmaya başlanmıştır. COVID 19 Pandemisi ile ortaya çıkan ortamsal koşullar kuşkusuz birçok farklı yönlerden irdelenebilir. Bununla birlikte Pademi'nin küresel düzeyde ekonomik ve toplumsal yaşantıyı kökten etkilemesinden dolayı 2020 yılının bir kırılma noktası olacağı bir ölçüde tarihin yeniden yazılacağına ilişkin iddialar mevcuttur (Schwap ve Malleret, 2020; UN, 2020).

Bu makalede öncelikle COVID 19 Pandemisi ile birlikte ortaya çıkmış olan toplumsal ve ekonomik ortam küresel düzeyde irdelenecek, daha sonra da bu ortamın muhtemel gelişim eğilimleri tartışmaya açılacaktır.

\subsection{Pandemi ile Birlikte Dönüşen Toplumun Ana Unsurları; Risk, Kapatılmışlık, Gözetlenmişlik.}

COVID 19 Pandemisi'nin yarattığı toplumsal ortamı en iyi anlamlandıracak olan kavramın "risk" kavramı olduğuna yukarıda değinilmişti (Mol, 2000: 125; Beck, 1994:205). Bu bağlamda "kapatılmışlık," “öngörülemezlik,” “çaresizlik,” ve "güven bunalımı,” (Foucault, 2000, Lyotard, 1984; Harvey, 1990) gibi kavramlar COVID 19 Pandemisi’nin yarattığı ortamsal koşulları ifade edebilecek kavramlardır (Bavel, 2020; Fiorillo ve Gorwood, 2020). Bunun ötesinde, Pandemi koşullarında ortaya çıan sosyal izolasyon ve karantina koşullarının yarattığı, internet ve sosyal medya ağlarına olan bağımlılık ise "gözetim toplumu" kavramı ile ifade edilebilecek olan bir ortamı yarattığı söylenebilir. Şimdi tüm bu kavramların COVID 19 Pandemisi’nin ortaya çıkardığı toplumsal ortamı anlamak ve anlamlandırmak açısında operasyonel olarak nasıl kullanılabileceğine değinmek gerekmektedir.

Ulrich Beck'in 1990'larda ortaya attığı ve 20 yy.da toplumların içinde bulunduğu durumu tanımlamak için kullandığ "risk toplumu” kavramının COVID 19 Pandemisi'nin yarattığı ortamsal koşulları ifade etmek 
için bir hareket noktası, temel olarak kullanılmasının nedeni, Pandemi koşullarının büyük bir risk ve öngörülemezlik içermesidir. COVID 192019 yılı Kasım ayında ortaya çıkmış, kısa bir sürede hızla yayılarak tüm dünyayı etkisi altına almış ve 2020 yılı başında, Dünya Sağlık Örgütü (WHO) tarafından Pandemi olarak ilan edilmiştir. Mart 2021 itibariyle bir yılda 2,568,720 kişinin ölümüne ve 115,408,709 kişinin enfekte olmasına yol açmıştır (https://covid19.who.int). Bunun yanında, ilk ortaya çıkışından itibaren üzerinden bir yıldan fazla zaman geçmesine rağmen, aşısının bulunmuş ancak tedavi edici bir ilacının bulunamamış olması riskin en önemli belirleyeni olan öngörülemezlik durumunu ortaya koymaktadır. Bununla birlikte, Pandemi’de dünyanın birçok ülkesinde ikinci, hatta üçüncü dalga olarak ifade edilen aşamaya geçilmiş ve bununla birlikte Pandemi'nin ölümcül ve enfekte edici etkileri giderek artmaktadır. Buna karşın yakın ve orta vadede, bundan sonraki seyrinin nasıl olacağı hakkında öngörüde bulunmak oldukça zordur. Bu durum tam da Ulrich Beck'in ifade ettiği risk ve bu riskin yarattığ 1 öngörülemezlik durumunun ifadesidir.

Riskin ana unsurunu oluşturan öngörülemezliğin yanı sıra, Pandemi koşullarını ifade edebilecek olan diğer bir kavram ise kapatılmışlık duygusudur. Kapatılmışlık belirli bir mekanda dış faktörlerden izole olarak yaşamını sürdürmek zorunda kalarak hapsolma durumunu ifade etmektedir. Toplumun geniş kesimlerinin, özellikle Pandemi’nin ilk aşamalarında 20 yaş altı ve 65 yaş üstü nüfusun ve zaman zaman toplumun tamamının sokağa çıkmasının kısıtlandığı durum tam da kapatılmışlık ve hapsolma durumunu tanımlamaktadır. İnsanların aylarca evlerinde kapalı kalarak adeta ev hapsinde tutulmaları ve bir anlamda toplumsal ilişki ağlarından toplumsal bağlamlarından koparılmış olmaları tam da kapatılmışlık durumunu ifade etmektedir (Foucault, 2000). Bu bağlamda bu kapatılmışlık kavramı ile ifade edilebilecek olan psikososyal duygu durumundan çıkış büyük bir önem taşımaktadır (Pfefferbaum ve Nort, 2020).

Pandemi koşullarında ortaya çıkmış olan kapatılmışlık durumunu en iyi ifade edebilecek metaforlardan birisi belki de Micheal Foucault'nun Hapishane’nin Doğuşu (2005) adlı eserinde bahsettiği Panoptikon (sekizgen cezaevi) metaforudur. Panoptikon cezaevi fikri ilk kez 1791'de Jeremy Bentham tarafindan 
ortaya atılmış; sekizgen yapıda ve ortasında, tüm mahkumların her anlarının gözetlendiği bir gözetleme kulesinin bulunduğu bir cezaevini ifade etmektedir. Bu gözetleme kulesinde yer alan gardiyan ya da gözcü kule etrafinda yapılanmış ve kuleye bakan duvarı cam ile kaplanmış olan hücrelerde kalan mahkumların her anlarını izleyebilmekte, ancak mahkumlar gardiyanı görememektedir. Bu yapı içinde mahkumların her anları izlenmekte ya da izlenmekte olduğu izlenimi verilmektedir. Ancak mahkumlar kendilerini izleyeni ya da gerçekten izlenip izlenmediklerini ya da ne zaman ve kadar süre ile izlendiklerini görememektedirler. Bu durum zaten kapalı ortamda yer alan mahkumlar üzerinde ilave bir psikolojik baskı yaratmakta ve deyim yerindeyse cezalarının şiddetini bir kat daha arttırmaktadır.

Foucault'nun modern/postmodern toplumun içinde bulunduğu durumu ifade etmek için kullandığ "kapatılmışl1k" ve Panoptikon cezaevi metaforu, Pandemi koşullarında ortaya çıkan sokağa çıkma kısıtlamaları ile birlikte adeta bir metafor olmaktan çıkarak, tam anlamıyla bir geçekliğe dönüşmüştür denilebilir. Uzun süreler evlerinde hapsolarak kapalı kalmış, toplumsal bağlamlarından kopmuş ve izole olarak yaşamlarını sürdürmek zorunda kalmış olan geniş toplum kesimlerinin içinde bulunulan durumu kapatılmışlığın yanı sıra "fare kapanına kapatılmışlık" olarak ifade etmek mümkündür.

Çünkü evlerinde uzun süre kapalı kalanlar, bu süre içerisinde; adeta fare kapanındaki fare gibi, sadece evlerinin sınırlı alanı içinde yürüme ve hareket etme imkanı bulabilmişler, hatta bazıları yürümeyi dahi unuttuklarını ifade etmişlerdir. Yukarıda, Foucault'nun Panoptikon cezaevi modelini modern toplumun içinde bulunduğu durumu tanımlamak için bir metafor olarak kullandığına değinilmişti. Buna göre aslında, artık gözetim toplumu olarak da ifade edilen modern toplum ve hatta postmodern toplumdaki yaşantı tamamen Panoptikon cezaevine benzemektedir. Buna göre, devletin kontrolünde olan iletişim ve ideolojik

\footnotetext{
${ }^{2}$ Pandemi koşullarının toplum üzerinde yarattığı etkileri araştırmak için yapılan görüşmelerde, 65 yaş üzeri bir görüşmeci; kendileri için sokağa çıkma kısıtlaması getirildiğinden beri, her gün evin içini adımladığını ve evin enine 10 metre ve boyuna 12 olduğunu ve odaların her birinin boyutlarını ezberlediğini ve Panemiden önce sokakta yürüyerek yaptığı yürüyüşleri artık evin içinde, evi enine boyuna "arşınlayarak" yaptığını ifade etmiştir. Sanıyorum bu durum Foucault'nun "kapatılmışlık" kavramından referansla "fare kapanına kapatılmışlık" olarak ifade edilebilir.
}

$\mathrm{SAD} / \mathrm{JSR}$

Cilt / Volume 24 Say1 / Number 2 
araçlarla insanların tüm anları izlenmekte ve insanların neredeyse mahrem yaşantıları bile ortadan kalkmaktadır. 1980'li yıllardan önce film ve televizyon endüstrisi ve eğitim başta olmak üzere diğer ideolojik araçlarla ve bir ölçüde dolaylı olarak yapılan bu gözetleme süreci; 1980'li yıllarda internetin ve 1990’1ı yıllarda sosyal medya araçlarının ortaya çıkmasıyla artık dolaysız olarak, doğrudan geçekleşmektedir. Pandemi koşullarında oraya çıkmış olan kapatılmışlık ve hatta fare kapanına kapatılmışlık duygusu, internet ve sosyal medyanın çok yaygın bir şekilde kullanılmasıyla perçinlenerek olarak "gözetlenmişlik" ve "gözetim toplumu”nun somut tezahürlerine dönüşmüştür (Foucault, 2000). Pandemi koşullarında, sokağa çıkma kısıtlamasından dolayı, alışılagelmiş sosyal ilişkilerin (Sezal, 2003; Akan, 2003; Tuna, 2017) fiilen mümkün olmamas1 ve sosyal bağlamların ortadan kalkmas1 ile birlikte, insanlar sosyal ilişkilerini internet üzerinden kurulan sosyal medya ağları aracılığı kurmuşlardır. Günümüzde dünyada 5 milyardan fazla kişi internet ve sosyal medya ağlarına bağlanmaktadır (https://dijilopedi.com/2020-dunya-internet-sosyal-medya-ve-mobil-kullanim-istatistikleri/). İnternet ve sosyal medya ağlarının bu Pandemi sürecinde bu kadar fazla oranda hayatımıza girmiş olması bir ölçüde "gözetlenmişlik" durumunun somut tezahürü olarak karşımıza çıkmaktadır.

Özellikle Facebook adı verilen sosyal medya platformu, kullandığı algoritmalarla kullanıcıların arkadaşlarının kim olduğunu, ne yiyip içtiğini, ne giydiğini, ne kullandığını takip etmekte ve buna göre kullanıcılara uygun reklamlar sunmaktadır. Bu aslında bir bakıma kullanıcıların her anınızın gözetlendiği anlamına gelmektedir. Yukarıda ifade edilen örnekler, sosyal medya araçları ile toplumun gözetlenmesinin sadece birkaç örneğini oluşturmaktadır. Sosyal medya ağları adeta toplumun gözetlenmesi "gözetim toplumu" kavramının tam anlamıyla gerçeklik kazanmasına yol açmıştır denilebilir. Bunun ötesinde, Pandemi ortamında evlerinde hapis kalan toplum kesimlerinin internet ve sosyal medya araçlarında yer alması/gözetlenmesi durumu, Panoptikon cezaevinde mahkumların gözetleme kulesinden gözetlenmesine benzetilebilir. Başka bir deyişle Pandemi’den dolayı insanların evlerinde kısıtlı kalması, cezaevinde kalma 
durumunu ve insanların evlerinde internet ve sosyal medya aracılığı ile sosyalleşmesi ise cezaevindeki gözetleme kulesinden gözetlenmeleri durumunu temsil etmektedir.

\subsection{Sanal Toplum}

Pandemi koşulları altında yukarıda ifade edilen toplumsal yaşamın adeta Panoptikon cezaevi metaforu ile anlatılan duruma dönüşmesinin ötesinde, sokağa çıkma kısıtlaması ve fiziki sosyal ilişkilerin fiilen ortadan kalkması sonucu internet ve sosyal medya ağları üzerinden kurulmuş olan bir "sanal toplum"dan (Lea, Yatsuki, Matsuda, 1997) söz etmek mümkündür. Sanal toplum olarak ifade edilen süreç aslında, 1980’ler ve 1990'lardan sonra hızla yaygınlaşan yeni bir toplumsal evrenin bir bileşeni olarak ortaya çıkmaktadır. Küreselleşme (Wallerstein, 1979; Benton ve Reclift, 1994; Buttel, 2000), post-modern koşullar (Lyotard, 1984; Harvey, 1990), geçmodernite ya da ekolojik modernite (Spaargeren, Mol ve Buttel, 2000), risk toplumu (Beck, 1994) gibi kavramlarla ifade edilen bu dönemin diğer ifade biçimi de bilgisayar ve internetin etkisine vurgu yapmak amaciyla kullanılan dijital topum ya da burada ifade edildiği biçimiyle sanal toplumdan söz etmek mümkündür (Lea, Yatsuki, Matsuda, 1997). Sanal toplum kavramı aslında yeni ortaya çıkmış olan bir kavram değildir. 1980'li yıllarda internetin sivil amaçlarla kullanılarak yaygınlık kazanmaya başlaması ile birlikte; ekonomik, toplumsal ve bilim dünyasına ilişkin yaşamın internet üzerine kaymaya başlamasıyla ortaya çıkmaya başladığı söylenebilir. Böylelikle, internet üzerinden kurulan bu yeni ilişkiler ağına kısaca "sanal toplum” denilmiştir (Lea, Yatsuki, Matsuda, 1997; Gürcan, 2020). Bu süreç 1990’l1 yıllarda internet üzerinden kurulan sosyal medya ağlarının ortaya çıkıp yaygınlaşmaya başlamasıyla birlikte daha da hızlanmıştır. Nihayet 2020'li yıllara gelindiğinde artık, gerçeklikler dünyasına paralel olarak internet ve sosyal medya ağları üzerinden kurulmuş bir sanal dünya iyice belirgin hale gelmiş ve Pandemi koşulları bu süreci müthiş bir şekilde hızlandırmıştır. Bu süreçte bilgisayar ya da akıllı telefonlar aracılığı ile sosyal medya ağlarına giren ya da sanal dünyada kendini var ya da görünür kılanların sayısı 5 milyarı aşmış olup bu "sanal toplumun” da daha belirgin görünür hale gelmesine yol açmıştır. 
"Big data" denilen ve küresel düzeyde sosyal medya kullanıcılarını, dolayısıyla tüketici davranışlarını (wearesocialit) izleyerek/gözetleyerek belirlemeye yönelik algoritmalar geliştirmeye yönelik teknolojiler üreten ve bu teknolojileri anında sosyal medya ve e-ticaret platformlarında uygulamaya sokan entegre sistemlerden söz etmek mümkündür. Ayrıca Pandemi sürecinde de üretilen bu "big data" toplumun Pandemi konusundaki bilgilenmesi, neyin önemli olduğu ve neyin önemli olmadığı konusunda yönlendirilmeye çalışılmıştır (Milan, 2020). Bu durum diğer faktörlerin yanında aynı zamanda "gözetim toplumu” olgusunun somut bir görünümü olarak karşımıza çıkmaktadır.

Tüm bunların üstüne COVID 19 karantina şartlarından dolayı artık eğitim de yüz yüze ve okullarda verilmekten çıkmış sanal ortamda uzaktan verilmeye başlanmıştır. Dünya genelinde uzaktan ve sanal ortamda eğitim görenlerin sayısının 2 milyara yaklaştığı ve Türkiye'de ise bu rakamın 25 milyonu aştı̆̆ tahmin edilmektedir. Dolayısıyla dünyadaki toplumların büyük bir kısmı, adeta yeni oluşturulan küresel sanal internet ağları üzerinden yürüyen sanal bir dünyanın içine hapsolmuş durumdadır. Ekonomi başta olmak üzere, eğitim, kültür, politika ve diğer tüm iş ve işlemler büyük ölçüde artık bu sanal dünyada yürümektedir. Bir ölçüde, önce küresel ve sanal bir dünya yaratılmış daha sonra da insanların ve toplumların sınırları çizilen bu sanal dünyada kendilerine biçilen rolleri oynamaları beklenmiştir. Bu saptama öylesine gerçektir ki; başını sokacak damı, hatta belki de yiyecek ekmeği bile olmayan bir Afrikalı, bir cep telefonuna sahip olarak sosyal medya yoluyla kendisine çizilen sanal dünya içinde yer almay1 düşünmektedir. Bunu cep telefonu ve internet talebinin en hızlı artışının Afrika'da olmasından anlamak mümkündür (fundalina.com).

Küreselleşme, post-modern koşullar, internet ve sosyal medyanın hızla gelişmesi ve yaygınlaşması toplumu da çok hızlı bir şekilde etkisi altına almış ve toplumda dönüştürücü bir etki yapmıştır. Bu bağlamda alışılageldik iş ve ilişki biçimleri geniş ölçüde değişmiş toplumun çok geniş kesimleri artık internet ve sosyal medyayı temele alan iş ve ilişki biçimleri içine girmiştir. Bu süreç adeta sınıfsal konumları da yatay kesen bir süreç haline gelmiş, internet ve sosyal medyada yer almak ya da bu sürecin içinde görünür olmak 
yeni statü göstergesi, entelektüel kapasite göstergesi hatta Bourdieu'nun (2002) kavramıla ifade edilecek olursa, kültürel sermayeye sahip olmanın bir göstergesi haline gelmiştir. Sosyal medya platformlarında yer almak ve temsil edilmek her sınıfta ve sosyal statüde yer alanlar için şu ya da bu şekilde vazgeçilmez bir gereklilik olarak görülmeye başlanmıştır. Aslında bir sanal alem olan sosyal medyada yer almak ve görünür olmak adeta yeni bir varoluş, (https://curatti.com/social-media-existential-threat/) kendini ifade etme ve hatta kimlik oluşturma biçimi haline gelmiştir (Lea, Yatsuki, Matsuda, 1997; Gürcan, 2020).

Yukarıda ayrıntılı olarak açıklandığı gibi, geçmişi 1980'li ve 1990’lı yıllara dayanan, "sanal toplum" olgusunun Pandemi koşullarında çok daha büyük oranda gerçeklik kazandığı söylenebilir. Sadece alış-veriş ve bankacılık gibi doğrudan ekonomik faaliyetler değil; basın-yayın, eğlence faaliyetleri gibi alanlar ve eğitim başta olmak üzere birçok kamusal hizmetler de internet ve sosyal medya ağları üzerinden yürütülmeye başlanmıştır. Bu bağlamda özellikle eğitim gibi yüz milyonlarca öğrenciyi ve milyonlarca öğretmeni ilgilendiren bir alan büyük ölçüde internet ve sosyal medya ağları üzerinden yürütülmeye başlanmıştır. Aslında uzaktan eğitim süreçlerinin geçmişi de uzun yıllar öncesine dayanmaktadır. Ancak Pandemi koşullarında her düzeydeki eğitim süreçleri kaçınılmaz olarak internet üzerinden yürütülmeye başlanmıştır. Bu bağlamda, geleneksel, yüz yüze ya da örgün eğitim süreçlerine alışkın olan öğrenciler ve öğretmenler yeni, sanal mecralarda gerçekleşen uzaktan eğitim süreçlerine ayak uydurmakta oldukça zorlanmışlardır. Bununla birlikte sistemin, taşıdığı tüm sorunlarına rağmen ağır aksak da olsa yürümekte olduğunu ifade etmek mümkündür. Ayrıca internet altyapısının ve diğer teknik altyapının yetersizliği gibi nedenler, internet üzerinden uzaktan eğitimin sürdürülmesini zorlaştırılmakta, hatta yüz milyonlarca öğrenci bu olanaklara sahip olmadığı için olamadığı eğitim olanaklarından da mahrum kalmışlardır (UN, 2020). Ancak her hal ve şart altında artık eğitim süreçlerinin büyük ölçüde ve kalıcı olarak internet ve sosyal medya üzerinden, uzaktan eğitim araçları ile yürütüleceği görülmektedir. Bu sürecin eğitimin biçim ve içeriğini değiştireceği ve eğitimin bundan böyle yeniden inşa edileceği öngörülmekte ve toplumun, politika 
yapıcıları, öğretmenlerin ve öğrencilerin bu yeni süreçlere uyum sağlamak konusunda daha yoğun çaba harcamaları gereği ortaya çıkmaktadır (Carvalho ve Hares, 2020).

Pandemi koşulları, yukarıda ifade edilen "sanal toplum"un oluşum sürecini kaçınılmaz olarak hızlandırmıştır. Bu bölümde Pandemi koşullarında ortaya çıkan ortamsal koşulların "kapatılmışlık", "gözetlenmişlik" ve "sanal toplum” kavramlarıyla ifade edildiğini gördük. Bundan sonraki bölümde ise toplumun bundan sonra hangi yöne doğru evrilebileceğine ilişkin olasıllklar üzerinde durulacaktır.

\section{TOPLUM BUNDAN SONRA NASIL BİR YÖNE DOĞRU EVRÍLEBİLİR.}

Yukarıda, COVID 19 Pandemisi ile ortaya çıkan toplumsal ortamın "kapatılmışlık", "gözetilmişlik" ve "sanal toplum" kavramları ile ifade edilmesinin uygun olacağı değerlendirilmişti. Bu bölümde ise yukarıda genel çerçevesi çizilen ortamsal koşullardan hareketle, toplumların bundan sonra hangi yöne doğru evrilebileceğine ilişkin olarak bir değerlendirme yapılacaktır. Bu bağlamda ortaya konulacak argüman dört noktada açıklanabilir. Bu bağlamda işaret edilmesi gereken ilk unsur dayanışma (Durkheim, 1964) ve dayanışma ekonomileridir (Aykaç, 2018). Dayanışma aslında çok eski bir toplumsal nitelik, hatta toplum olmanın temel niteliğidir denilebilir. Ancak neoliberalizm sürecinde kısmen gözden düşmüş görünen dayanışma fikrinin, Pandemi koşullarında yeniden gündeme geldiği görülmektedir. Dayanışma fikrinin yeniden gündeme gelmesiyle ilişkili olarak, daha yoğun olarak tartışılmaya başlanan diğer bir kavram da dayanışma ekonomileridir. Dayanışma ekonomilerinin 1990'lı yıllardan itibaren özellikle Latin Amerika'daki bazı uygulamalar bağlamında gündeme geldiği ancak Pandemi koşullarında daha da belirginleştiğini ifade etmek mümkündür. Toplumun bundan sonra hangi yöne evrilebileceğine ilişkin olarak belirtilmesi gereken ikinci unsur, Pandemi koşullarıyla birlikte ortaya çıkmış sanal ortamda kurulmuş olan dayanışmadır. Pandemi koşulları ile birlikte internet gibi sanal ağlar üzerinden toplumun bir anlamda yeniden kurulduğu ve bu toplumun sanal ağlar üzerinden etkin bir dayanışma duygusu ortaya koyduğu varsayılmaktadır. Toplumsal yaşamın geleceğine ilişkin olarak ifade edilmesi gereken diğer üçüncü unsur ise sosyal devlet (Seçkin, 2010) ilkesinin yeniden gündeme gelmesidir. 1980’li yıllardan 
itibaren yükselişe geçmiş olan küreselleşme ve neo-liberalizm eğilimlerine bağl1 olarak, görece gündemden düşmüş gibi görünen sosyal devlet ilkesi (Sallan Gül, 2004), Pandemi koşullarında yeniden gündeme gelmiştir. Pandemi koşullarında sosyal devletin ne kadar önemli olduğunun bir kez daha farkına varılmış ve sosyal devletin ve sosyal politikaların gerekliliği yeniden ve yoğun olarak tartışılmaya başlanmıştır (Schwap ve Malleret, 2020; OECD, 2020; ILO, 2020). Pandemi koşullarının yeniden gündeme getirdiği ve bundan sonra gelişme eğilimi görülecek olan en son gelişmenin insan çevre ilişkileri bağlamında olacağ 1 öngörülmektedir. Bu bağlamda doğanın yeniden keşfi ve doğaya geri dönüş eğilimlerinin artması ve insan müdahalesi olmadığında doğanın kendini ne kadar hızlı bir şekilde onarabildiğinin farkına varılması bu bağlamda ortaya çıkacak olan gelişmelerdir (Şahin, 2020). Bu bölümde, Pandemi'nin ortaya çıkardığı koşullara bağlı olarak ortaya çıkmış olan eğilimler ve bu eğilimlerin hangi yöne doğru evrilebileceğine ilişkin olarak yukarıda sayılan olasılıklar mümkün olduğunca ayrıntılı olarak ele alınacaktır.

\subsection{Dayanışma ve Dayanışma Ekonomileri}

COVID 19 Pandemi koşullarında öne çıkmış olan toplumsal niteliklerden birisinin, dayanışma olgusunun yeniden keşfedilmiş olması olduğuna yukarıda değinilmişti. Aslında dayanışma olgusu toplumsal yaşamda çok eski dönemlerden beri var olan ve hatta sosyolojinin kurucularından olan Durkheim'ın (1964) toplum modelinin ana kavramlarında birisidir. Durkheim dayanışmayı bir ölçüde toplumu tanımlayan temel unsurlardan birisi olarak görür ve toplumun insanların sıradan bir şekilde bir araya gelmesiyle oluşmadığını, insanları toplum yapan şeyin aslında aralarındaki dayanışma olduğunu ifade eder. Ancak özellikle küreselleşme ve neoliberalizm süreçleri ile birlikte bu dayanışma duygusu da bir anlamda ikinci plana itilmiştir (Sallan Gül, 2004). Fakat Pandemi koşulları ile birlikte ortaya çıkan ortamsal koşullar, dayanışma olgusunu yeniden gündeme getirmiştir. Bunun temel nedeni; Pandemi koşularında insanlar sokağa çıkma kısıtlamasından dolayı üretimden kopmuş, işini ve gelirini kaybetmiş ve sonuçta yoksullaşmış ve hatta bazı toplum kesimlerinin açlık tehdidi ile karşı karşıya kalmış olmalarıdır (UN, 2020; Martin ve diğ., 2020). Bu noktada bazen sosyal devlet destekleri yetersiz kalmış ve işsizlik ve yoksulluğun yarattığı toplumsal 
etkilerden (UN, 2020) kurtulmanın ancak dayanışma ile mümkün olabileceği yönündeki toplumsal farkındalık artmıştır (OECD, 2020). İnsanlar sınırlı kaynaklarını paylaşmışlar ve böylelikle işsizlik ve yoksulluğun etkilerini kısmen önleme yollarını aramışlardır. Bunun ötesinde aslında geçmişi çok eskilere dayanan, ancak 1990’lı yıllardan itibaren özellikle Latin Amerika ülkelerindeki bazı uygulamalar ile tartışılmaya başlanan "dayanışma ekonomileri” de (Aykaç, 2018) Pandemi koşulları altında bir kez daha ve daha yaygın olarak tartışılmaya başlanmıştır. Kooperatifler aracılığı ile küçük üreticinin desteklendiği ve üreticiler ile tüketicilerin özellikle internet ve sosyal medya platformları aracılı̆̆ karşıya geldiği ve böylelikle üreticilerin, tüketicileri doğrudan desteklediği üretim ve tüketim modelleri daha sıklıkla tartışılmaya başlanmıştır (ILO, 2020).

Dayanışma ve dayanışma ekonomilerinin, Pandemi koşullarında gündemin üst sıralarına gelerek daha yaygın bir şekilde tartışılmaya başlanması, 1980'li yıllardan itibaren giderek artan ölçüde ivme kazanan neoliberelizm ve küreselleşme eğilimleri (Spaargeren, Mol ve Buttel, 2000; Giddens, 1990, 1991) ile yakından ilişkilidir. Bu bağlamda küreselleşme ekonomik anlamda sınırların ortadan kalkması hatta siyasi anlamda da sınırların giderek anlamını yitirerek, dünyanın adeta tek bir üretim ve tüketim pazarı haline gelmesi en azından bu yöne doğru bir gidiş eğilimini ifade etmektedir. Neoliberalizm ve küreselleşme süreçleri ile birlikte, üretim ve tüketim kanalları, ulusal hatta uluslararası düzeyde tekelleşerek ve piyasalarda egemenlik kurarak, yerel aktörlerin piyasaya girişine engel olmuşlar ve böylelikle fiyatlar genel düzeyini yükseltmişlerdir (Baran, 1973; Wallerstein, 1979; Gare, 1995; Spaargeren, Mol ve Buttel, 2000). Bununla bağlantılı olarak özellikle yoksul toplum kesimleri, beslenme başta olmak üzere en temel gereksinimleri karşılamakta zorluklar çekmeye başlamışlardır. Pandemi koşullarında, insanların yaygın bir şekilde işlerini kaybetmesi ve yoksulluğun artmasıyla birlikte, başta gıdaya ulaşım olmak üzere, temel gereksinimlerin karşılanması daha da büyük toplumsal sorunlar haline gelmiştir. Pandemi koşullarında 40 ile 60 milyon arasında yeni insanın mutlak yoksulluğa ve 1 milyar 200 milyon kişinin işini kaybetmesinden dolayı hiç gelirinin olmadığı koşullara sürüklendiği tahmin edilmektedir (UN, 2020). İşte bu ortamsal 
koşullar altında insanlar, yoksulluğun etkilerini dayanışma ile aşmaya çalıştıkları gibi, dayanışmayı ön planda tutan üretim ve tüketim modelleri yeniden gündeme gelmiş, kooperatifleşme bu bağlamda ilk akla gelen stratejilerden birisi olmuştur (ILO, 2020).

Bunun yanı sıra; neolibarelizm küreselleşme süreçleri ile birlikte artan tekelleşme eğilimleri bağlamında, özellikle büyük ölçekli tarımsal üretimin yanı sıra küçük ölçekli tarımsal üretim de gündeme gelmiştir. Bu küçük ölçekli tarımsal üretim stratejisi de Pandemi koşullarına bir ölçüde yeniden keşfedilmiş ya da yeniden farkına varılmış olan bir üretim stratejisidir (https://www.platinonline.com/dergi/yeni-nesil-ciftciler1025247). Buna göre küçük ölçekli üretim; çok büyük arazilerde, küresel süpermarket zincirleri için yapılan büyük ölçekli tarımsal üretime bir ölçüde alternatif olan; herkesin kendi küçük arazisinde, temelde kendi ihtiyacını karşılamaya yönelik olarak yapılan küçük ölçekli tarımsal üretimi ifade etmektedir. Bu küçük ölçekli ve bir ölçüde geçimlik temeline dayanan üretimin, Pandemi gibi küresel kriz dönemlerinde, yoksul kesimlerin besin maddelerine ulaşmasını kolaylaştıran bir strateji olduğu yaygın olarak tartışılmaya başlanıştır. Bu üretim stratejisi aynı zamanda gıda güvenliği (Yaralı, 2018) açısından da son derece önemli olup; bir yandan küçük üreticiyi destekleyici bir nitelik taşıdığı gibi, diğer yandan gıdaya ulaşmakta zorluk çeken yoksul toplum kesimlerinin gıdaya ulaşmasını kolaylaştıracak bir strateji olabilir. Bu aynı zamanda tarım sektörünün en yoksullarından olan küçük üreticiler ile diğer yoksul toplum kesimleri arasında bir dayanışmayı da mümkün kılabilir (ILO, 2020).

Dayanışmanın ve dayanışma ekonomilerinin sadece tarımsal ürünlerin üretim ve tüketimi ile sınırlı olmadığı, diğer sektörlerde de çok sayıda benzer dayanışma örneklerinin olduğu görülmektedir. Örneğin kullanılmış giysilerin ihtiyacı olanlara, karşılıksız ya da çok düşük fiyata ulaştırılması, kullanılmış ders ve okul araç gereçlerinin ve diğer kullanılmış ev eşyalarının aynı şekilde karşılıksız ya da çok düşük fiyata ihtiyaç sahiplerine ulaştırılası bu dayanışma tiplerinin örneklerinden sadece birkaçıdır. Aslında bu dayanışma tipleri toplumda çok eskiden beri var olan ancak, Pandemi koşullarında adeta bir kez daha keşfedilmiş dayanışma stratejileridir. Dolayısıyla Pandemi koşullarının öğrettiği ve kalıcı olması beklenen 
derslerden birisi, toplumsal dayanışmanın öneminin bir kez daha öne çıkmış olası ve toplumsal düzeyde kavranmış olmasıdır denilebilir (ILO, 2020). Önümüzdeki dönemde toplumsal dayanışmanın ve buna bağlı olarak dayanışma ekonomilerine ilişkin eğilimlerin daha da güçleneceğini ifade etmek mümkündür.

\subsection{Pandemi Koşullarında Toplumsal Dayanışma}

Pandemi şartları toplumun evlerine kapanarak izole olmasına; geleneksel sosyal ilişkilerin, sosyal bağların ve bağlamların kısmen ortadan kalkmasına yol açmıştır (Siedner ve diğ., 2020). Bu noktadan hareketle Pandemi koşulları altında toplum, yukarıda da ifade edildiği gibi, aslında hafızasında var olan dayanışma gibi özelliklerini yeniden keşfetmiş ve bir ölçüde yeni örgütlenme ve yeniden yapılanma yolları aramaya başlamıştır. Pandemi koşullarında toplumun kapatılmışlık ve gözetilmişlik (Foucault, 2000; 2005) duygusuna benzer psikolojik duygu durumları içinde olduğu gözlenmiştir (Fiorillo ve Gorwood, 2020). Toplum bu duygu durumlarına karşı, yukarıda ifade edilen, daha geleneksel dayanışma tiplerinden (Durkheim, 1964) bir ölçüde farklı olarak sanal sosyal medya ağlarını kullanarak bir toplumsal dayanışma içine girmiştir. Bu yeni dayanışma tipi, geleneksel sosyal ilişkilerin ve bağların Pandemi koşullarının yaratmış olduğu izolasyondan dolayı bir ölçüde gerçekleşememesi sonucu, sosyal medya platformları üzerinden kurulan ve yukarıda "sanal toplum” (Lea, Yatsuki, Matsuda, 1997) diye ifade ettiğimiz sosyal ilişkiler ağı ve bu ilişkiler ağına bağlı olarak ortaya çıkmış olan bir toplumsal dayanışma tipidir.

Pandemi öncesinde belirli fiziki mekanlarda ve belirli ve bir ölçüde tanımlanmış biçimde gerçekleşen sosyal ilişkiler, sosyal ağlar ve sosyal dayanışma; Pandemi koşullarından dolayı mümkün olmayınca, tüm bu sosyal etkinliklerin mümkün olduğunca internet ve sosyal medya platformları üzerinden gerçekleşmesi söz konusu olmuştur. İnternet ve sosyal medya platformları, bir ölçüde varoluş alanına ve aynı zamanda sosyal ilişkilerin ve sosyal dayanışmaların da kurulduğu platformlara dönüşmüştür. Formel eğitimin büyük ölçüde internet ve sosyal medya platformları üzerinden gerçekleşmesinin ötesinde, insanlar bu araçları kullanarak haberleşmişler, sosyalleşmişler, toplantılar bu mecralarda yürütülmüş hatta bu mecralarda çok geniş katılımlı konserler düzenlenmiştir (https://www.billboard.com/articles/columns/pop/9335531/coronavirus- 
quarantine-music-events-online-streams). Evlerine hapsolmuş olan toplum kesimleri bu platformlar aracılığı ile paylaşımlarda bulunmuşlar, birbirilerinin ihtiyaçlarını belirlemişler ve bu ihtiyaçları gidermeye çalışmışlardır. Başka bir deyimle, Pandemi koşullarında özellikle sokağa çıkma kısıtlamasından en yoğun olarak etkilenen 20 yaş altı ve 65 yaş üstü nüfus içine düştükleri "kapatılmışlık" ve "gözetlenmişlik" duygularından, internet ve sosyal medya platformları aracılığı kurulmuş olan sosyal ağlar ile kısmen kurtulabilme olanağına kavuşmuştur (Oosterhoff ve Palmer, 2020; Pfefferbaum ve Nort, 2020).

\subsection{Neoliberalizmin İflası ve Sosyal Devletin Yeniden Keşfi}

Pandemi koşullarının toplumsal düzeyde öğrettiği derslerden birincisi dayanışma ve dayanışmanın öneminin kavranması ise ikincisi, özellikle sağlık ve eğitim ile ilgili olarak sosyal devletin bir ölçüde yeniden keşfedilmesidir (Seçkin, 2010; OECD, 2020; ILO, 2020; Schwap ve Malleret, 2020). Tabii ki sosyal devletin keşfi yeni değildir, uzun yıllardan beri sosyal devletin modern toplumda ne kadar önemli ve fonksiyonel olduğu bilinmektedir (Baran, 1973; Wallerstein, 1979; Gare, 1995; Spaargeren, Mol ve Buttel, 2000). Ancak yukarıda değinildiği gibi, 1980’li yıllarda artan neolibearlizm ve küreselleşme eğilimlerine paralel olarak, tüm ekonomik faaliyetlerin yanı sıra, eğitim ve sağlık başta olmak üzere tüm toplumsal hizmetlerin de piyasada koşullarında üretileceği ve satılacă̆ı yönündeki bir anlayış tüm dünyada ağırlık kazanmaya başlamıştır (Sallan Gül, 2004). Dolayısıyla tüm ekonomik faaliyetlerin yanı sıra sağlık ve eğitim gibi, ekonomik boyutunun yanında sosyal boyutu da olan faaliyetler de piyasa koşullarındaki değişim değeri kadar değerli hale gelmiştir. Bu bağlamda eğitim ve sağlığa yönelik sosyal destekler azalmış, bu sektörlerin maliyeti piyasa koşullarında belirlenmeye başlanmış ve sonuçta yoksul kesimlerin ulaşması mümkün olmayan maliyetlere ulaşmıştır (Martin ve diğ., 2020).

Küresel kapitalizm COVID 19 Pandemisine sosyal devletin büyük ölçüde etkisini yitirdiği koşullar altında yakalanmıştır. Sağlığa ilişkin sosyal destek imkanlarının son derece yetersiz kalması ve ilk başta bir aşının bulunamamış olmasından dolayı COVID 19'a yol açan virüs çok hızlı bir şekilde yayılmış ve milyonlarca kişi çok kısa sürede enfekte olmuştur. Ayrıca etkili bir tedavisinin de neredeyse mümkün olmaması ya da 
çok pahalı olmasından dolayı söz konusu hastalık önemli ölçüde öldürücü olmuştur. Bu ortamsal koşullar altında, özellikle yoksul kesimlerin temel sağlık hizmetlerine ulaşması çok zorlaşmış ve bu durumun da etkisiyle COVID 19'a yol açan virüsünün yol açtığı enfeksiyondan kaynaklanan ölümlerin sayısı dünya genelinde 2,5 milyonu aşmıştır. COVID 19 Pandemisi'nin en hızlı yayıldığı ve ölümlerin en fazla görüldüğü ülkeler; şaşırtıcı olmayan bir şekilde, ABD, İngiltere, İspanya, İtalya gibi, neoliberalizm ve küreselleşmenin en yaygın olduğu ve buna bağlı olarak sosyal devlet ve sosyal sağl1k hizmetlerinin en zayıf olduğu ülkeler olmuştur. Bu ülkeler başta olmak üzere dünyanın birçok ülkesinde, sosyal sağlık altyapısının yetersiz kalmasından dolayı enfekte olan hastalara yeterli sağlık hizmeti götürülememiş (UN, 2020) ve hatta hayatını kaybeden hastaların ölü bedenlerinin toplanılarak uygun bir şekilde defnedilmesi bile mümkün olamamıştır.

Sosyal sağlık hizmetlerinde görülen yetersizlik, eğitim alanında da görülmüştür. Pandemi koşullarından dolayı yüz yüze eğitime ara verilmiş, bunun yerine internet üzerinden sağlanan uzaktan eğitime geçilmiştir. Ancak gerek internet altyapısının çok yaygın bir kullanım için yetersiz kalması, gerekse özellikle yoksul toplum kesimlerinin internete ulaşımının yetersiz olması ve evlerinde dijital eğitim araçların olmamasından dolayı, bu kesimlerinin çocukları zaten sınırlı düzeyde yararlandıkları eğitim olanaklarından ya çok daha sınırlı düzeyde ya da hiç yararlanamaz duruma gelmişlerdir. Pandemi koşullarında eğitim olanaklarından yararlanamayan öğrencilerin sayısını 1 milyar 200 milyonu aştığı tahmin edilmekte olup (UN, 2020), Afrika'da eğitim çağında bulunan 500 milyon çocuktan sadece 1 milyonu Pandemi koşullarında eğitim alabilmiştir (Carvalho ve Hares, 2020). Bu durum, sağlık açısından olduğu gibi, eğitim açısından da alt sosyo-ekonomik düzeyde bulunanlar ile üst sosyo-ekonomik düzeyde bulunanlar arasındaki toplumsal eşitsizliği daha da arttırmıştır (Martin ve diğ., 2020; UN, 2020).

Başta eğitim ve sağlık olmak üzere toplum yaşamının birçok alanında görünen ve kapitalizm ve daha somut olarak neoliberalizmin somut sonuçları olan bu eşitsizlikler çok uzun süreden beri tartışılmaktadır. Ancak Pandemi koşulları ile birlikte söz konusu eşitsizliklere dayalı sorunlar çok daha belirgin, görünür ve hatta 
sistemin sürdürülebilirliğini tehdit eder boyutlara ulaşmıştır (Schwap ve Malleret, 2020). Bu bağlamda neoliberalizm ve küresel kapitalizmin aslında yapısal nedenlerle, Pandemi koşullarında yeterli refleksi gösteremediği ve bunun sonucunda Pandeminin etkisinin bu kadar yıkıcı olduğu yönünde tartışmalar vardır. Hatta bu tartışmalar kapitalizm ve neoliberalizmin en yüksek düzeydeki sözcüleri tarafından dile getirilmiştir. Küresel kapitalizmin bir ölçüde sözcülügünü üstlenmiş görünen Dünya Ekonomik Forumun Yönetim Kurulu Başkanı olan Klaus Schwap bu durumu, Time Dergisinde 22 Ekim 2020 tarihinde yayınlanan yazısında açıklıkla ifade etmiştir. Schwap, kapitalizmin sürdürülebilirliğinin bu haliyle tehlikede olduğu ve sosyal devlet ve sosyal sorumluluk ilkelerinin yeniden gündeme getirilerek, kapitalizmin yeniden kurulması gerektiğini ifade etmiştir. Bu durum zaten uzun süreden beri dile getirilen neoliberalizmin iflas ettiği tartışmalarını yeniden alevlendirmiştir.

Neoliberalizmin mevcut haliyle Pandemi koşullarında gereken refleksi gösterememesi sonucunda, sosyal devletin ne kadar gerekli olduğuna ilişkin görünürlük ve bilinirliğin toplumsal bilinçte de kalıcı etkiler bırakacağı ve bunun sonucunda sosyal devletin çok daha ciddi ve kurumsal düzeyde bir toplumsal talep haline geleceğini ifade etmek mümkündür (OECD, 2020; ILO, 2020). Ayrıca bu durumun sadece, kapitalizmin yeni bir dönemsel krizi olarak görülerek, küçümsenecek bir durum olmanın ötesinde; daha derin ve kalıcı izler bırakacağı öngörülmektedir (Schwap ve Malleret, 2020). Sosyal devlet ilkesini rafa kaldırmış görünen neoliberalizm açısından, bu ilkenin kaçınılmaz olarak yeniden gündeme gelmesi kaçınılmazdır (OECD, 2020; ILO, 2020; Schwap ve Malleret, 2020).

\subsection{Doğanın Yeniden Keşfi ve Doğaya Geri Dönüş Eğilimlerinin Artması}

Pandemi koşullarında ortaya çıkan toplumsal eğilimlerden birisi de hiç kuşkusuz insanın doğaya ilişkin bakış açısında oldukça köklü değişikliklerin ortaya çıkmasıdır. Bunun temel nedeni ise Pandemi koşullarında özellikle sokağa çıkma kısıtlamalarından kaynaklanan kapatılmışlık duygusunun yarattığı psikolojik baskı ile birlikte insanların zaten son derece kısıtlı olan doğa ile olan ilişkileri tamamen kopma noktasına gelmiştir. Dolayısıyla bu ortamsal koşullarda insanlar içine düştükleri olumsuz psikolojik duygu 
durumlarından kurtulmanın bir aracı olarak doğayla iç içe bir yaşama özlem duymuşlar ve bu özlem duygusu doğaya geri dönüş eğilimi şeklinde tezahür etmiştir. Bu eğilimlerin somut bir tezahürü olarak, doğanın insanoğlu tarafından bir kez daha yeniden keşfedilmesi söz konusu olmuştur (Spaargeren, Mol ve Buttel, 2000; Tuna, 2013). Bir diğer değişim ise doğanın insan müdahalesi olmadığında kendini hızla yenileyebileceğinin bir kez daha farkına varılmasıdır (Şahin, 2020; Forster, P.M., Forster, H.I., Evans, M.J.ve diğ., 2020). Şimdi toplum doğa ilişkileri ve doğanın toplum tarafından algılanışı açısından son derece önemli olan bu iki değişim eğilimine daha ayrıntılı olarak bakalım. Doğanın yeniden keşfi aslında yeni değildir. İnsan toplumlarının doğayla olan ilişkisi, sanayi devrimi ile birlikte tamamen ve büyük ölçüde kopma ve doğaya yabancılaşma sürecine girmiştir. 19. yy. sonlarından itibaren iyice hızlanan bu kopuş ve yabancılaşma süreci, 20 yy.ın son çeyreğinde adeta zirve noktasına ulaşmıştır (Tuna, 2013). Ancak bu bağlamda, 20.yy.ın ikinci yarısından itibaren bu kopuş ve yabancılaşmanın kendisine çok ağır faturalar çıkardığının farkına varmaya başlayan insan toplumları, doğayı yeniden keşfetmeye ve doğayla bozulan ilişkilerini yeniden kurmaya ve düzeltmeye başlamıştır (Spaargeren, Mol ve Buttel, 2000; Beck, 1992). Bununla birlikte insanoğlu doğayla bozulan ilişkilerini aslında hiçbir zaman yeniden kuramamıştır. Bu bağlamda hava, su ve toprak kirliliği ve küresel 1sınma gibi çevresel felaketlerle, doğayla bozulan ilişkisinin faturasını uzun süreden beri ödemektedir. Ancak insan toplumları, Pandemi koşullarında doğayı bir kez daha, yeniden keşfetmiştir denilebilir (Şahin, 2020). Çünkü COVID 19 virüsünün insan sağlığı üzerinde yaptığı etki ile ilgili olarak insanlar, nefes almanın değerini bir kez daha anlamışlardır. Çünkü COVID 19 virüsü sonucu oluşan enfeksiyonun akciğerlere inmesi sonucunda, nefes almak giderek zorlaşmakta ve insanlar sonuçta nefes alamamaktan dolayı boğularak ölmektedirler (Gallagher, 2020). Dolayısıyla insanın biyolojik varoluşunun temelini oluşturan nefesin/havanın ne kadar önemli olduğunun bu vesile ile farkına varılmış olması son derece önemlidir.

Bunun ötesinde insanlar Pandemi koşullarından dolayı, uzun süreler evlerinde hapis kalmışlar ve bu bağlamda zaten son derece sınırlı olan doğayla olan ilişkileri, kelimenin tam anlamıyla kopma noktasına 
gelmiştir. Pandemi koşullarında, özellikle ve çocuklar ve yaşlılar için uygulanan sokağa çıkma kısıtlaması sonucu, bu toplum kesimlerinin doğayla tek rutin ilişki kurma noktaları olan parklara dahi çıkamamışladır. İnsanların yukarıda ifade edilen, son derece sınırlı doğayla ilişki olasılıkları tamamen ortadan kalkınca doğanın ve doğal ortamlarda bulunmanın ve doğal ortamlarda nefes almanın önemi bir kez daha keşfedilmiştir. Bu bağlamda doğanın ve doğal yaşamın değerinin farkına varılmış ve insanlar doğayı keşfetme eğilimi içine girmişlerdir (Şahin, 2020).

Doğayı yeniden keşfetme eğilimleri, giderek doğaya geri dönüş eğilimlerini de hızlandırmıştır. Doğaya geri dönüş eğilimleri, bir ölçüde Pandemi koşulları sonucunda ortaya çıkan "kapatılmışlık" ve "gözetlenmişlik" duygu durumlarından çıkışın bir yolu olarak görülmeye başlanmıştır. Tarihsel olarak insanoğlunun yaşantısı aslında, daima doğayla iç içe, eşitlik temeline dayalı ve dostane bir şekilde olmuştur. İnsanoğlunun doğal yaşamı aslında doğaya uygun olan yaşamdır ve sanayileşme ile birlikte ortaya çıkmış olan modern sanayi toplumu olarak adlandırdığımız yaşam biçimi insan doğasına uygun değildir. İnsanoğlu milyonlarca yıl doğayla iç içe ve doğaya uygun bir şekilde yaşamış, sadece yaklaşık son 300 yıldan beri doğadan kopuk ve doğaya yabancılaşmış bir şekilde yaşamaktadır. Daha önce de vurgulandığı gibi, doğayla karşılıklılık temeline dayalı bu dostane ilişki endüstri devrimine kadar sürmüştür (Spaargeren, Mol ve Buttel, 2000; Tuna, 2013). Pandemi koşulları ve evde kalma kısıtlamaları altında doğanın ve doğal yaşamın farkına varabilenler ve evde kalma kısıtlamasında kurtulabilenler, süratle doğaya geri dönüş eğilimine girmişlerdir. Bunun somut göstergesi olarak, büyük metropollerde yaşayanlar, kırsal alanlarda ve doğa içinde köy evlerinde yaşamayı ve hatta toprakla uğraşarak çiftçilik yapmayı yoğun bir şekilde tercih etmeye başlamışlardır. Doğaya geri dönüş eğilimlerinin bir parçası olarak, büyük kentlerden işini gücünü bırakarak, köylere göç eden ve burada toprakla uğraşıp çiftçilik yapanlara verilen isim olan yeni çiftçilik de Pandemi koşullarında giderek artan bir eğilim olarak karşımıza çıkmaktadır. Doğaya geri dönüş eğitimini eyleme geçirebilenlerin oranı halen oldukça düşük düzeydedir. Ancak ekonomik koşulları görece iyi durumda olan emekliler ile henüz emekli olmamış ancak beyaz yakalı ve profesyonel meslek sahibi ve görece iyi düzeyde 
kazanca sahip olarak kısmen birikim yapmış olanlar doğaya geri dönüş eğilimini eyleme geçirebilmektedirler (https://www.platinonline.com/dergi/yeni-nesil-ciftciler-1025247).

İnsan doğa ilişkilerinin, Pandemi koşulları altındaki değişimine ilişsin olarak ortaya en son vurgulanması gereken nokta ise insan müdahalesi olmadığında doğanın kendini hızla yenilemesidir. Pandemi koşullarından dolayı üretim ve tüketim hızla düşmüş, turizm ve seyahatler durmuş, motorlu araçlar ve tüm kara, deniz ve hava ulaşım araçları çalışmamıştır (UN, 2020). Bunun sonucunda hava, su ve toprak kirliliği azalmış, balıklar ve diğer deniz canlıları denizlere ve göllere geri dönmüş ve sucul ekosistemler yeniden canlanmıştır (Şahin, 2020). Özellikle küresel ısınmaya yol açan sera gazları emisyonlarında çok ciddi düşüşler meydana gelmiştir (Forster, P.M., Forster, H.I., Evans, M.J.ve diğ., 2020). Pandemi koşullarından dolayı insanların sokağa çıkamaması sonucu, sokaklar vahşi hayvanlara kalmış ve domuz, geyik gibi doğal ortamlarda yaşayan hayvanlar şehir merkezlerine kadar inmişlerdir (Şahin, 2020). Modern toplum öncesinde vahşi hayvanlara ait olan doğal alanlar, kentleşme ve sanayileşme ile birlikte insanlar tarafından işgal edilmişti; ancak Pandemi koşullarından insanlar ortadan çekilince, vahşi hayvanlar aslında kendilerine ait olan alanlara geri dönmüşlerdir. Dolayısıyla Pandemi koşullarında sanayi üretimi ve ulaşım durunca ve insanlar ortadan kaybolunca, doğa hızla kendini yenilemiştir. Bu aslında insan doğa ilişkileri açısından son derece önemli bir farkındalık olmalıdır ve gelecekte bu eğilimlerin güçlenmesi beklenmektedir (Şahin, 2020).

$\mathrm{SAD} / \mathrm{JSR}$

Cilt / Volume 24 Sayı / Number 2 


\section{SONUÇ}

Pandemi koşulları yeni bir toplumsal ortamın ortaya çıkmasına yol açmıştır. Buna göre, Pandemi' den dolayı getirilen sokağa çıkma kısıtlamaları sonucunda insanlar sokağa çıkamamış ve evlerinde hapis kalmışlardır. $\mathrm{Bu}$ durum toplumda "kapatılmışlık" duygusu yaratmıştır. Bunun sonucunda insanlar daha fazla oranda internet ve sosyal medya platformlarında yer almışlar ve bu durum adeta bir bağımlılı̆ga ve sonuçta gözetilmişlik duygusunun ortaya çıkmasına yol açmıştır. Bu "kapatılmışlık" ve "gözetilmişlik" duygusu tam olarak Foucault'nun Panoptikon cezaevi metaforu ile anlatmaya çalıştığı bir cezaevi durumunun ortaya çıkmasına yol açmıştır.

Bunun ötesinde Pandemi koşulları, internet ve sosyal medya araçlarıyla ortaya çıkan ve "sanal toplum" olarak adlandırılan bir toplum yapısının ortaya çıkmasına yol açmıştır. Buna göre, alışılageldik toplumsal ilişkiler, yapılar ve bağlamlar Pandemi koşullarından dolayı bir ölçüde işlevini yitirmeye başlayıp işlemez hale gelince, sosyal ilişkiler ve ağlar ağırlıklı olarak internet ve sosyal medya ağları üzerinden kurulmaya başlanmıştır. İnternet ve sosyal medya ağlarında yer alan, bu ağlar üzerinden alış-veriş eden ve bu ağlar üzerinden kendisini ifade edenlerin sayısı 5 milyarı aşmıştır. Dolayısıyla aslında Pandemi koşulları öncesinde de var olan, ancak Pandemi'den sonra giderek yaygınlık ve derinlik kazanan internet ve sosyal medya üzerinden kurulan ve "sanal toplum” olarak adlandırılan yeni bir toplumdan söz etmek mümkündür.

$\mathrm{Bu}$ ortamsal koşullar altında toplumun bundan sonra nasıl bir yöne doğru evrilebileceğine ilişkin olarak değişik olasılıklardan söz etmek mümkündür. Bu olasılıklar arasında otoriteryen eğilimlerin artması ve bunun siyasal sistemlere yansıması olarak otoriter devlet sistemlerinin yaygınlaşması olasılığından söz edilebilir. Bu makale çerçevesinden bu olasılıklar ele alınmamış; yukarıda değinilen "kapatılmışlık" ve “sanal toplum” kavramsallaştırmaları üzerinden toplumun ne yöne evrilebileceğine ilişkin bir tartışmaya girilmiştir.

Bu olasılıklardan ilki dayanışmanın ve dayanışma ekonomilerinin yeniden gündeme gelmesidir. Pandemi koşullarında insanların işini kaybetmesi ve yoksullaşmanın artması sonucu özellikle yoksul toplum 
kesimleri, besin maddeleri başta olmak üzere, temel ihtiyaç maddelerine ulaşamaz olmuştur (UN, 2020). $\mathrm{Bu}$ bağlamda özellikle yoksul kesimlerinin gıdaya ulaşmasında bir strateji olarak toplumsal dayanışma ve dayanışma ekonomileri (Aykaç, 2018; ILO, 2020) gündeme gelmiştir. Dayanışma stratejisinin ve sanal toplum yapılanmasının bir devamı ve bileşeni olarak toplumun sanal ağlar üzerinden bir toplumsal dayanışma biçimi oluşturmuşlardır. İnternet ve sosyal medya ağları üzerinden kurulan dayanışmayı ifade eden bu sanal dayanışma özellikle 20 yaş altı ve 65 yaş üstü toplum kesimlerinin toplumsal soyutlanmışlık, "kapatılmışl1k" ve "gözetlenmişlik" duygularından çıkmalarını sağlayacak bir strateji olarak ortaya çıkabilir. Bunun ötesinde, 1980'li yıllardan itibaren yaygınlaşmaya başlayan neoliberalizm ve küreselleşme eğilimleri bağlamında sosyal devlet ilkesi görece gözden düşmüş, sosyal sağlik hizmetleri ve eğitime ayrılan kaynaklar azalmıştır. Dünya bu şartlar altında Pandemiye yakalanmış ve sosyal sağlık altyapısının yetersizliğinden dolayı, Pandemi ile yeterince mücadele edilememiş ve sonuçta 2,5 milyondan fazla kişi hayatını kaybetmiş ve 100 milyondan fazla kişi enfekte olmuştur. İşte bu ortamsal koşullarda, sosyal devlet ilkesi yeniden gündeme gelmiştir (OECD, 2020; ILO, 2020; Schwap ve Malleret, 2020). Bundan sonra sosyal devlet ilkesinin daha yoğun olarak tartışılacağı ve görece ağırlık kazanacağı öngörülmektedir. En son olarak, Pandemi koşuları altında doğa yeniden keşfedilmeye başlanmış ve buna bağlı olarak doğaya geri dönüş eğilimleri ortaya çıkmıştır. Pandemi koşulları, doğanın ve doğal yaşamın önemi ve buna bağlı olarak doğaya uygun yaşamın insan için doğal yaşam olduğunun farkına varılmıştır. Bunun ötesinde, insan müdahalesinin olmadığı durumda doğanın hızla kendisini yenilediği; hava, toprak ve sudaki kirliliğin ortadan kalktığı, denizlerin, göllerin ve akarsuların temizlendiği balıkların ve diğer sucul ekosistemlerin yeniden oluştuğu, vahşi hayatın yeniden canlanarak, vahşi hayvanların şehir merkezlerine kadar indiği görülmüştür (Şahin, 2020). Dolayısıyla, sonuç olarak Pandemi’nin bize öğrettiği en önemli ders doğaya uygun, doğal yaşamın ne kadar önemli olduğu; doğaya uygun olmayan yaşamın ise mutluluk getirmediği gibi, felaketlere neden olduğudur. Pandemi koşullarında bu farkındalığın arttığı ve bundan sonra doğaya uygun yaşam eğilimlerinin artacağı öngörülmektedir.

SAD / JSR

Cilt / Volume 24 Sayı / Number 2 


\section{SUMMARY}

COVID 19 appeared in November 2019 in city of Wuhan, China. The Pandemic swiftly dispersed all around the world and defined as Pandemic by World Health Organization in the early 2020. More than 2.5 million people died and 115 million people infected by COVID 19. Accordingly, world has been changed deeply and everything has been redefined. COVID 19 Pandemic would be evaluated from so much different perspectives.

However, the argument defended in this article is based upon that social conditions of COVID 19 Pandemic could be defined as "closedness" and "watched." The concepts of "closedness" and "watched" are coming from Michael Foucault's magnificent book Discipline and Punish: The Birth of the Prison (1995). Foucault defined social conditions of modern society as a prisoner in the prison that called Panopticon. The social conditions of society under impact of Pandemic are much more concrete example of prisoner in the panopticon prison. Furthermore, social conditions of the society under impact of Pandemic are defined as "virtual society." Because internet and social media are much more affective in the Pandemic conditions. As a result of these major conditions four major points could be defined to understand structure of new social conditions. Firstly, solidarity, solidarity economy reappeared as major factors of new social conditions. Actually, solidarity is an old concept to define society; however, this is devaluated in the under impact of neoliberalism. However, these concepts are reemerged in the Pandemic conditions. Solidarity economy is another reemerged concept in the pandemic conditions. The concept suggested in this article that basically is defined as solidarity in the virtual society using internet and social media platforms. Another factor that could be defined as major characteristics of new society is appearance of social state as a result of bankruptcy of neoliberalism. The last factor that could be defined as major character of new social conditions in the Pandemic is rediscovery of the nature and back to nature. 


\section{KAYNAKÇA}

Akan, V. (2003). Birey ve Toplum. İ. Sezal (Ed.) Sosyolojiye Giriş içinde (s. 79-104). Ankara: Martı Yayınları.

Aykaç, A. (2018). Dayanışma Ekonomileri: Üretim ve Bölüşüme Alternatif Yaklaşımlar, İstanbul: Metis Yayınları.

Baran, P. (1973). Political Economy of Growth. Harmondswortd: Peguin.

Bavel, J. V. ve diğerleri (2020). Using Social and Behavioural Science to Support COVID-19 Pandemic Response. https://psyarxiv.com/ (Erişim tarihi, 30.04.2020).

Beck, U. (1994). Risk Society: Toward a New Modernity, Thousand Oaks, CA: Sage.

Benton, T., Redclift, M. (1994). Social Theory and the Global Environment. London: Routledge.

Bourdieu, P. (2002). Distinction: A Social Critique of the Judgement of Taste. Cambridge: Harvard University Press.

Buttel, F. (2000). Classical Theory and Contemporary Environmental Sociolgy, Environment Global Modernity, Ed: Spaargaren, G., A. Mol, F. Buttel, International Sociological Association, London.

Carvalho, S. ve S. Hares. (2020). Six Ways COVID-19 Will Shape the Future of Education. Center for Global Development. https://www.cgdev.org/blog/six-ways-covid-19-will-shape-future-education

Durkheim, E. (1964). Division of Labour in Society. New York: Free Press.

Fiorillo, A., Gorwood, P. (2020). The Consequences of the COVID-19 Pandemic on Mental Health and Implications for Clinical Practice. European Psychiatry, 63(1), s. 25-35. E32. doi:10.1192/j.eurpsy.

Forster, P.M., Forster, H.I., Evans, M.J. ve diğ. (2020). Current and Future Global Climate Impacts Resulting from COVID-19. Nature Climate Change, 10, 913-919.

Foucault, M. (1995). Discipline and Punish: The Birth of the Prison. Vintage Books, New York.

Foucault, M. (2000). Büyük Kapatılma. I. Ergüder, F. Keskin (Çev.). İstanbul: Ayrıntı Yayınları.

Foucault, M. (2005). Hapishanenin Doğuşu. M. A. Kılıçbay (Çev.). İstanbul: İmge Yayınevi.

Gallagher, J. (2020). https://www.bbc.com/turkce/haberler-dunya-51910851

$\mathrm{SAD} / \mathrm{JSR}$

Cilt / Volume 24 Sayı / Number 2 
Gare, A. E. (1995). Postmodernizm and the Environmental Crisis. London: Routledge.

Giddens, A. (1990). The Consequences of Modernity. Cambridge: Polity Press.

Giddens, A. (1991). Modernity and Self-Identity in the Late Modern Age. Cambridge: Polity Press.

Gürcan, H. İ. (2020). https://www.ekodialog.com/Makaleler/internet-kuresellesme-sanal-toplummakale.html. (Erişim Tarihi: 26.08.2020).

Harvey, D. (1990). The Condition of Postmodernity an Enquiry into the Origins of Cultural Change. Blackwell Publishing, The Malden.

ILO, International Labor Organization. (2020). Çalışma Dünyasının Geleceği: Değişen Çalışma Dünyasında Işsirliği: $\quad$ Kooperatif Bir Geleceğe Doğru, https://www.ilo.org/wcmsp5/groups/public/---dgreports/--cabinet/documents/publication/wcms 559275.pdf. (Erişim tarihi: 21.11.2020).

Lea, R., Honda, Y., Matsuda, K. (1997). Virtual Society: Collaboration in 3D Spaces on the Internet Computer Supported Cooperative Work. The Journal of Collaborative Computing, 6: 227-250.

Lyotard, J. F. (1984). The Postmodern Condition: A Report on Knowledge. Manchester: Manchester University Press.

Martin, A., Markhvida, M., Hallegate, S., Walsh, B. (2020). Socio-Economic Impacts of COVID-19 on Household Consumption and Poverty. Economics of Disasters and Climate Change, 4:453-479.

Milan, S. (2020). Techno-Solutionism and the Standard Human in the Making of the COVID-19 Pandemic. Big Data \& Society, July-December: 1-7.

Mol, A. (2000). Globalization and Environment: Between Apocalypse-Blindness and Ecological Modernization. Spaargaren, G., Mol, A., Buttel, F. (Ed.), Environment Global Modernity içinde (s.121-150). London: International Sociological Association.

OECD. (2020). Social economy and the COVID-19 Crisis: Current and Future Roles. https://read.oecdilibrary.org/view/?ref=135 135367-031kjiq7v4\&title=Social-economy-and-the-COVID-19crisis-current-and-future-roles. 
Oosterhoff, B., Palmer,C. A. (2020). Psychological Correlates of News Monitoring, Social Distancing, Disinfecting, and Hoarding Behaviors among US Adolescents during the COVID 19 Pandemic. https://psyarxiv.com/ (Erişim tarihi: 30.04.2020).

Pfefferbaum, B., North, C. S. (2020). Mental Health and the Covid-19 Pandemic. The New England Journal of Medicine. https://www.nejm.org/doi/pdf/10.1056/NEJMp2008017?articleTools=true (Erişim tarihi: 30.04.2020).

Sallan Gül, S. (2004). Sosyal Devlet Bitti, Yaşasın Piyasa. İstanbul: Etik Yayınları.

Schwab, K., Malleret, T. (2020). Covid-19: The Great Reset. Forum Publishing,

Schwab, K. (2020). The Great Reset. Time Magazine, October 22, 2020.

Seçkin, T. (2010). Sosyal Devlet Anlayışının Gelişimi ve Dönüşümü. İstanbul:12 Levha Yayınları.

Sezal, İ. (2003). Neden Sosyoloji. İ. Sezal (Ed.), Sosyolojiye Giriş içinde (s.1-10). Ankara: Martı Yayınları.

Siedner, M. J., Harling, G., Reynolds, Z., Gilbert, R. F., Haneuse, S., Venkataramani, A. S., Tsai, A.C. (2020). Social Distancing to Slow the US COVID-19 Epidemic: Longitudinal Pretest-Posttest Comparison Group Study. Plos Medicine, 17 (8).

Spaargaren, G., Mol, A. P. J., \& Buttel, F. H. (2000). Introduction: Globalization, Modernity and Environment. Spaargaren, G., Mol, A. P. J., \& Buttel, F. H. (Ed.), Environment and Global Modernity içinde (s. 1-16). Sage.

Şahin, O. (2020). Tarihsel Fırsat: Pandemi, Doğa İşbirliği. İstanbul: 21. Yüzyıl Enstitüsü.

Tuna, M. (2013). Çevre Sosyolojisi. Eskişehir: Anadolu Üniversitesi Açıköğretim Fakültesi Yayını.

Tuna, M. (2017). Sosyolojinin Ortaya Çıkış Koşulları. M. Tuna (Ed.), Sosyolojiye Giriş içinde (s. 10-18). Ankara: Detay Yayınları.

UN. (2020). Brief\#2: Putting the UN Framework for Socio-economic Response to Covid 19 into Action: Insights. UN.

Wallerstein, I. (1979). The Capitalist World Economy. Cambridge: Cambridge University Press.

Yaralı, E. (2018). Gıda Güvenliği. Aydın: Andan Menderes Üniversitesi. 
https://dijilopedi.com/2020-dunya-internet-sosyal-medya-ve-mobil-kullanim-istatistikleri// (Erişim Tarihi: 12.11.2020)

https://www.platinonline.com/dergi/yeni-nesil-ciftciler-1025247 (Erişim Tarihi: 12.11.2020)

https://curatti.com/social-media-existential-threat/ (Erişim Tarihi: 19.11.2020)

https://www.billboard.com/articles/columns/pop/9335531/coronavirus-quarantine-music-events-onlinestreams (Erişim Tarihi: 20.11.2020)

https://wearesocialit.s3.amazonaws.com/think-forward-report2019/WAS_ThinkForward_2019_spread.pdf (Erişim Tarihi: 24.04.2020)

https://www.fundalina.com/2019-yili-global-dijital-raporu/ (Erişim Tarihi: 26.04.2020)

https://covid19.saglik.gov.tr/ (Erişim Tarihi: 26.08.2020)

https://covid19.who.int (Erişim Tarihi: 06.03.2021) 